amblyopia similar to tobacco amblyopia occurring as a result of malnourishment only, without any intake of tobacco. He also maintained that chronic, sustained, low-level cyanide intoxication, an experimental situation similar to that produced by smoking, does not cause any neurological effects. He has also challenged the exclusive role of $B_{12}$, pointing out that deficiency of vitamins other than $B_{12}$ can cause a tobacco-amblyopia-like syndrome which can be cured by an adequate diet supplemented by brewer's yeast. Also, Calhoun (1918) described similar paracentral as well as central scotomata in patients with pellegra which could be cured by the administration of nicotinic acid. Some claim has also been made for riboflavin deficiency as a factor in such amblyopias. While deficiency of vitamin $B_{1}$ may play a part in the causation of tobacco amblyopia, it is likely that other B vitamins and perhaps other nutritional factors produce the same pathological effect.

Whereas we found striking improvement with hydroxocobalamin in many of our cases, equal improvement was seen in others with cyanocobalamin, corticotrophin, or prednisolone, or spontaneously. Spontaneous recovery in optic neuritis is well known (Traquair, 1957; Walsh, 1957). Of the three patients with bilateral centrocaecal scotomata simulating tobacco amblyopia, one improved on corticotrophin alone, while another started improving spontaneously before hydroxocobalamin was given.

Hence two conclusions can justifiably be drawn from our cases. (1) That tobacco amblyopia is rare in this part of India in spite of a large population of vegetarian smokers. This is the more interesting in view of the fact that in the control series vegetarian smokers had high plasma thiocyanate levels and the lowest serum $B_{12}$ levels in the population. (2) That smoking, vegetarianism, and vitamin $B_{12}$ (either as hydroxocobalamin or as cyanocobalamin) play no part in the pathogenesis of isolated "idiopathic" optic neuritis as seen in our patients.

We are grateful for a grant from Glaxo Laboratories (India) Ltd., and for grant No. 01-011-1 from the National Institute of
Health of the U.S. Department of Health, Education, and Welfare. We thank the consultants of the Haji Bachooali Eye Hospital and the Kamatipura Eye Hospital for permission to study and treat patients under their care, and the drug controller and the chemical analyst, Government of Maharashtra, for analysis of liquor samples.

\section{References}

Adams, J. H., Blackwood, W., and Wilson, J. (1966). Brain, 89, 15.

Calhoun, F. P. (1918). American fournal of Ophthalmology, 1, 834.

Carroll, F. D. (1947). American fournal of Ophthalmology, 30,172

Chisholm, I. A., Bronte-Stewart, J., and Foulds, W. S. (1967). Lancet, 2, 450.

Clark, A. J. (1936). Journal of Tropical Medicine and Hygiene, 39, 269.

Dastur, D. K., Quadros, E. V., Wadia, N. H., Desai, M. M., and Bharucha, E. P. (1972). British Medical Journal, 3, 260.

De Grosz, S. (1949). Ophthalmologica, 118, 764.

De Grosz, S. (1949). Ophthalmologica, 118, 764. (1968). Lancet, 1, 896.
.

Foulds, W. S., Chisholm, I. A., Bronte-Stewart, J., and Wilson, T. M. (1969). British fournal of Ophthalmology, 53, 393 .

Freeman, A. G., and Heaton, J. M. (1961). Lancet, 1, 908.

Heaton, J. M., McCormick, A. J. A., and Freeman, A. G. (1958). Lancet, 2, 286.

Linnell, J. C., Hoffbrand, A. V., Peters, T. J., and Matthews, D. M. (1969). fournal of Clinical Pathology, 22, 742.

Linnell, J. C., Hussein, H. A.-A., and Matthews, D. M. (1970). Fournal of Clinical Pathology, 23, 820.

Matthews, D. M. (1971). British Medical fournal, 3, 659.

Monekosso, G. L., and Wilson, J. (1966). Lancet, 1, 1062.

Monekosso, G. L., and Wilson, J. (1966). Lancet, 1, 1062. McMenemey, W.' Cruickshank, E. K.' (1964). Brain, 87, 425.

Osuntokun, B. O., Langman, M. J. S., Wilson, J., and Aladetoyinbo, A. (1970). Fournal of Neurology, Neurosurgery and Psychiatry, 33, 663.

Osuntokun, B. O., Monekosso, G. L., and Wilson, J. (1969). British Medical fournal, $1,547$.

Smith, A. D. M. (1961). Lancet, 1, 1001.

Smith, A. D. M. (1962). British Medical fournal, 1, 1965.

Traquair, H. M. (1957). In Traquair's Clinical Perimetry, ed. C. I. Scott, 7th edn., p. 173. London, Kimpton.

Victor, M. (1970). In Miami Neuro-ophthalmology Symposium, ed. G. L. Smith, vol. 5 , p. 33. Florida, Huffman.

Walsh, F. B. (1957). In Clinical Neuro-ophthalmology, p. 309. Baltimore, Williams and Wilkins.

Wilson, J. (1963). Brain, 86, 347.

Wilson, J. (1963). Brain, 86, 347. $29,505$.

Wilson, J., Linnell, J. C., and Matthews, D. M. (1971). Lancet, 1, 259.

\title{
Hormonal Responses to Synthetic Luteinizing Hormone and Follicle Stimulating Hormone-Releasing Hormone in Man
}

\author{
G. M. BESSER, A. S. MCNEILLY, D. C. ANDERSON, J. C. MARSHALL, P. HARSOULIS, \\ R. HALL, B. J. ORMSTON, L. ALEXANDER, W. P. COLLINS
}

British Medical fournal, 1972, 3, 267-271

\section{Summary}

The effects of the gonadotrophin-releasing hormone, synthetic decapeptide luteinizing hormone/follicle stimu-

\section{St. Bartholomew's Hospital, London E.C.1}

G. M. BESSER, M.D., M.R.C.P., Senior Lecturer in Endocrinology

A. S. MCNEILIY, B.SC., PH.D., Research Lecturer.

Royal Postgraduate Medical School, London W.12

J. C. MARSHALL, B.SC., M.R.C.P., Research Fellow, Department of P. HARSOULIS, M.D., Research Fellow

Department of Medicine, Royal Victoria Infirmary, Newcastle upon Tyne 1

R. HALL, M.D., F.R.C.P., Professor of Medicine

B. J. ORMSTÖN, M.B., B.S., Research Fellow

L. ALEXANDER, M.B., M.R.C.P., Senior Medical Registrar

Department of Biochemical Endocrinology, Chelsea Hospital for Women, London W.16

W. P. COLLINS, B.Sc., PH.D., Principal Biochemist lating hormone-releasing hormone (LH/FSH-RH), have been studied in 18 normal men and five women in the follicular phase of their menstrual cycle. Rapid and dosedependent (25 to $100 \mu \mathrm{g}$ ) increases in serum immunoreactive LH were seen, which reached a peak 20 to 30 minutes after a rapid intravenous injection. Similar but much smaller increases in serum immunoreactive FSH were seen. These conclusions have been validated by using two different immunoassay systems for each hormone. The LH/FSH-RH therefore causes both LH and FSH release in man as in animals but does not affect growth hormone, thyrotrophin, or ACTH. The gonadotrophin responses were the same in the women as in the men but were insufficient in the men to cause statistically significant changes in the serum levels of the gonadal steroid hormones, testosterone or oestradiol, or in their precursors $17 \alpha$-hydroxyprogesterone or progesterone. In the women, however, there was a rise in oestradiol after the 100- $\mu \mathrm{g}$ doses. The use of LH/FSH-RH will provide an important test to define the level of the lesion in hypogonadal patients and also should be valuable in the treatment of some types of male and female in- 
TABLE I-Details of LH and FSH Radioimmunoassays

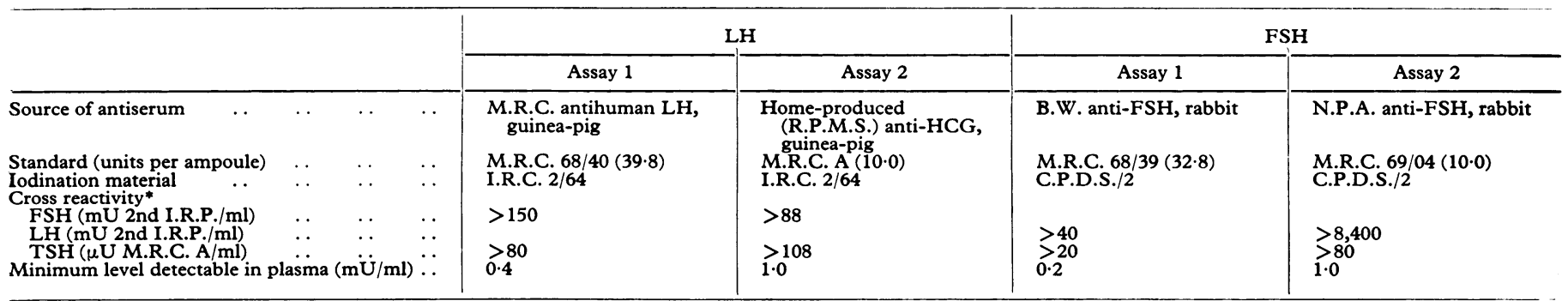

* Greater than stated amount would just be detected in the assay.

R.P.M.S. = Royal Postgraduate Medical School.

B.W. = Burroughs Wellcome.

N.P.A. = National Pituitary Agency.

I.R.C./64 provided by Dr. A. Stockell-Hartree.

I.R.P. = International Reference Preparation.

fertility. A simple and clinically useful LH/FSH-RH test of pituitary function is described (100 $\mu \mathrm{g}$ given intravenously), and the provisional normal responses of LH and FSH at 20 and 60 minutes are given.

\section{Introduction}

Pituitary secretion of the gonadotrophins, luteinizing hormone (LH) and follicle stimulating hormone (FSH), is under the control of the hypothalamus, which secretes specific gonadotrophin-releasing factor(s). Initially by using extracts of hypothalami it was reported that two distinct factors existed, one controlling LH release and the other FSH release (McCann and Dhariwal, 1964; McCann and Dhariwal, 1966), but it has proved possible to isolate only one purified polypeptide from these extracts (Schally et al., 1971a, 1971b). This decapeptide, pyro- GLU - HIS - TRP - SER - TYR - GLY-LEU-ARG - PRO GLY-NH $\mathrm{N}_{2}$ (Matsuo et al., 1971), obtained from pig hypothalami, has now been synthesized and it appears to release both LH and FSH from the pituitaries of animals (Schally, et al., 1971c). This compound is now referred to as luteinizing hormone/ follicle stimulating hormone-releasing hormone ( $\mathrm{LH} / \mathrm{FSH}-$ $\mathrm{RH}$ ), and we now report the effects in normal men and women of different doses of synthetic LH/FSH-RH on the secretion of $\mathrm{LH}, \mathrm{FSH}$, and the gonadal steroid hormones. In addition we have studied changes in other anterior pituitary hormones in order to establish the specificity of its effects in man. Because of the relatively poor specificity of existing radioimmunoassays for the gonadotrophins, LH and FSH assays were each carried out in two different systems.

\section{Subjects and Methods}

Eighteen normal male volunteers aged 23 to 40 years and five normal women aged 27 to 43 were studied. The synthetic LH/FSH-RH was prepared and made available by Hoescht Pharmaceuticals.

\section{INTENSIVE STUDY}

Three dose levels of LH/FSH-RH were used-25, 50, and $100 \mu \mathrm{g}$ given as a rapid intravenous injection in 1,2 , or $4 \mathrm{ml}$ of saline respectively at 10 a.m. Six men each received two dose levels at seven-day intervals, either 25 and $50 \mu \mathrm{g}$ or 50 and 100 $\mu \mathrm{g}$ or 25 and $100 \mu \mathrm{g}$ in random order, through an indwelling forearm venous cannula inserted under local anaesthesia 60 minutes before the injection. Two women each received 50 and $100 \mu \mathrm{g}$ during the follicular phases of subsequent cycles (between days 3 and 10). Blood was drawn 15 minutes and immediately before the injection and then at intervals afterwards for 48 hours. The cannulae were withdrawn after two hours and subsequent samples were obtained by venepuncture.

The following hormones were determined: $\mathrm{LH}$ and $\mathrm{FSH}$ (in two different radioimmunoassays), growth hormone (GH), thyrotrophin (TSH), cortisol as a measure of ACTH secretion, and the gonadal steroid hormones testosterone, oestradiol, $17 \alpha$-hydroxyprogesterone, and progesterone, as well as the total $17 \beta$-hydroxyandrogens.

\section{LIMITED STUDY}

A dose of $100 \mu \mathrm{g}$ was given intravenously to 14 further normal men and to three women between days three and six of their menstrual cycle, and blood was obtained for LH and FSH assay before and at 20 and 60 minutes afterwards.

Assay Methods.-LH and FSH were each assayed in duplicate in each of two separate systems, the characteristics of which are shown in Table I. Both assays used a second antibody method to separate bound and free hormones. Details of the radioimmunoassays for $\mathrm{GH}$ and $\mathrm{TSH}$ (Hall et al., 1972) and for the competitive protein binding method for $17 \beta$-hydroxyandrogens (Anderson, 1970) and fluorogenic corticosteroids (Hall et al., 1972) are given elsewhere.

Plasma Gonadal Steroids.-Progesterone, $17 \alpha$-hydroxyprogesterone, testosterone, and oestradiol were extracted with diethyl ether from separate aliquots of plasma $(5 \mathrm{ml}$ total), separated from closely related steroids on columns of Sephadex LH20, and determined by radioimmunoassay using antisera to progesterone- $11 \alpha$-hemis zucinate-BSA,$\quad 17 \alpha$-hydroxyprogesterone-3-oxime-BSA, testosterone-3-oxime-BSA, and oestradiol6-oxime-BSA (Collins, 1972).

\section{Results}

\section{INTENSIVE STUDY}

The basal values for each hormone were taken to be the mean of the values determined from the samples obtained 15 minutes and immediately before administration of LH/FSH-RH.

$L H$ and FSH basal values are shown in Table II. The increments above the basal values for the male subjects are shown in Figs. 1 and 2 for LH, and Figs. 3 and 4 for FSH.

It can be seen that there is an $L H$ rise within two minutes, that the response is dose-dependent, and that the peak levels are achieved at between 20 and 30 minutes after the injection. The normal values are approached again three to four hours after $25 \mu \mathrm{g}$ and about eight hours after 50 and $100 \mu \mathrm{g}$. There are no essential differences between the LH results obtained in the two assay systems. With one exception after a $25-\mu$ g dose each subject on each dose showed a rise in serum LH level which exceeded the upper limit of the normal range (assay $1: 6.9 \mathrm{mU} / \mathrm{ml}$, assay $2: 4.6 \mathrm{mU} / \mathrm{ml}$ ). 
TABLE II-Basal Serum LH and FSH Values in Intensively Studied Subjects

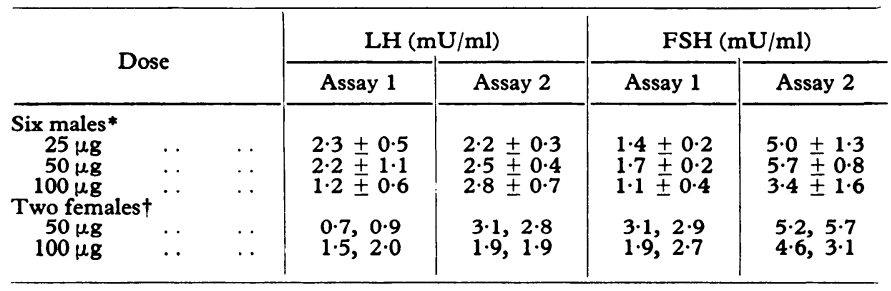

*Mean \pm 1 S.E. given.
tIndividual values given.

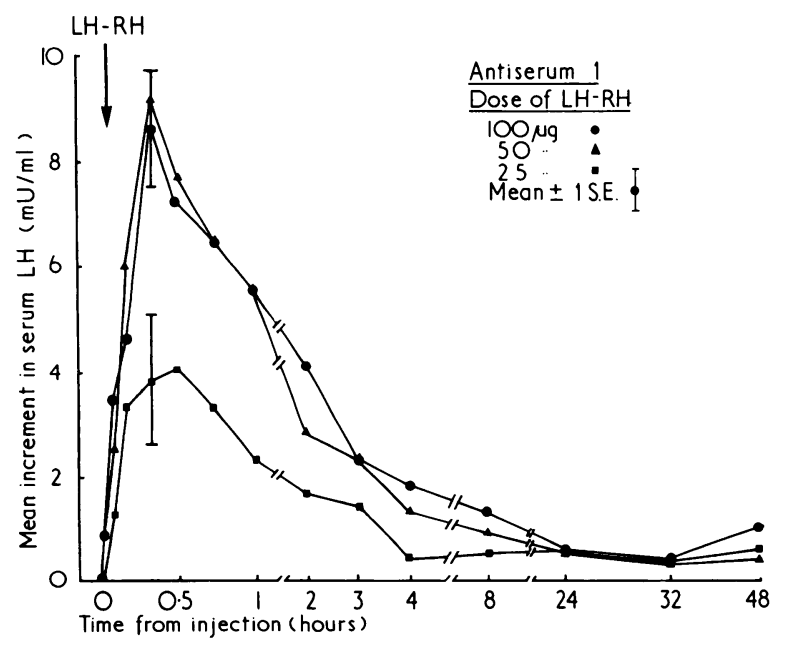

FIG. $1-\mathrm{LH}$ assay 1 . Mean increments in serum $\mathrm{LH}$ after 25,50 , and $100 \mu \mathrm{g}$ LH/FSH-RH in six normal males. Four subjects were studied at each dose level.

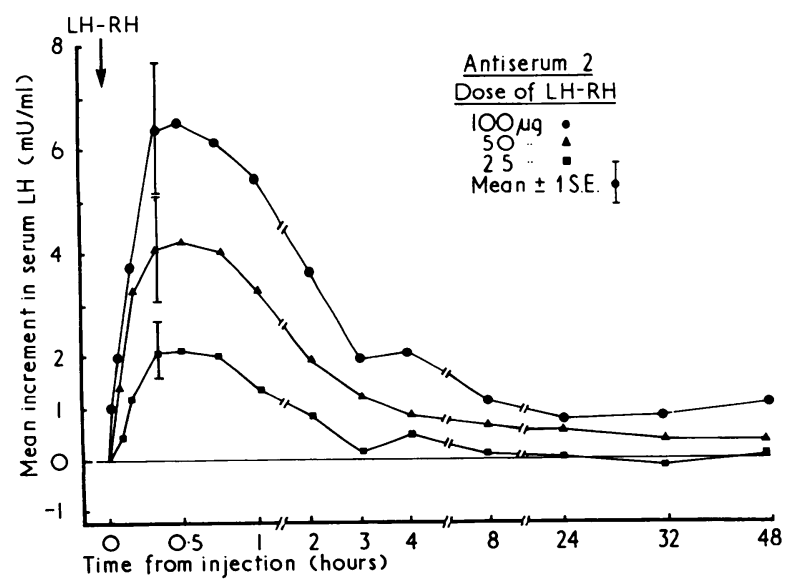

FIG. 2-LH assay 2. Legend as for Fig. 1.

The FSH levels showed similar but much smaller initial changes compared with the $\mathrm{LH}$ results. With assay 1 (Fig. 3) a significant rise was seen with each dose and there was a definite dose-response relationship. However, in every subject the increase in serum FSH was small and in no case did the response exceed the upper limit of the normal male range (4.5 $\mathrm{mU} / \mathrm{ml}$ ). With assay 2 (Fig. 4) a definite FSH response was seen with only 50 and $100 \mu \mathrm{g}$ doses of LH/FSH-RH and the effects appeared to be sustained for several hours longer.

The LH and FSH responses in the two women given 50 and $100 \mu \mathrm{g} \mathrm{LH} / \mathrm{FSH}-\mathrm{RH}$ in their follicular phases did not differ from the results obtained in the males and reached their peak at 20 to 30 minutes after the injection.

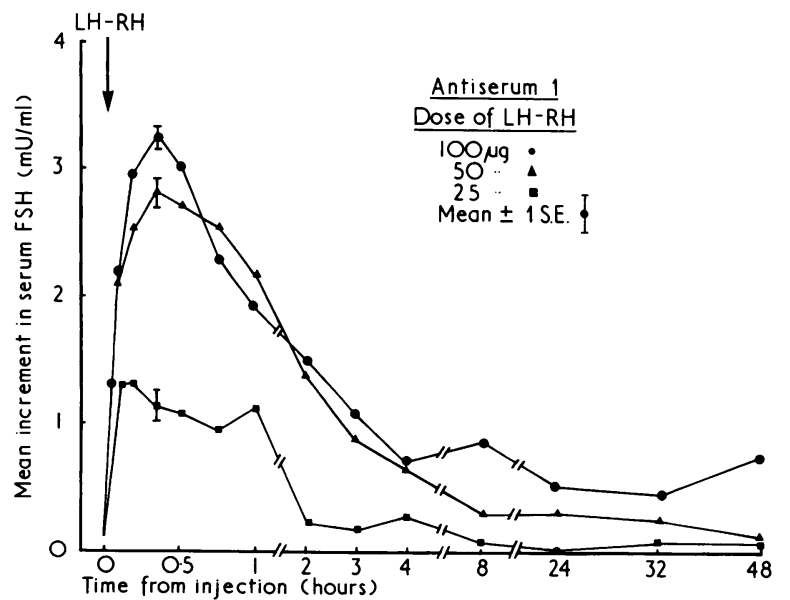

FIG. 3-FSH assay 1. Mean increments in serum FSH after 25, 50, and $100 \mu \mathrm{g}$ $\mathrm{LH} / \mathrm{FSH}-\mathrm{RH}$ in six normal males. Four subjects were studied at each dose level.

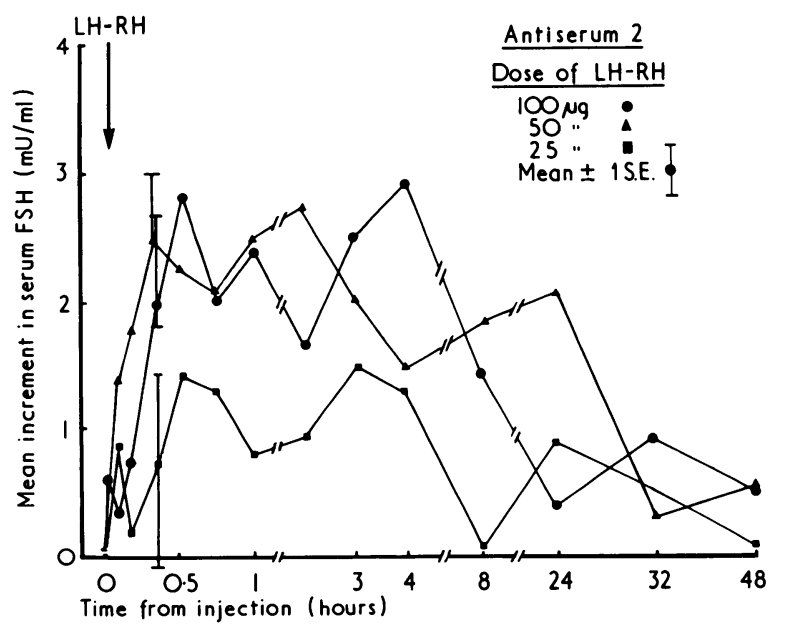

FIG. 4-FSH assay 2. Legend as for Fig. 3.

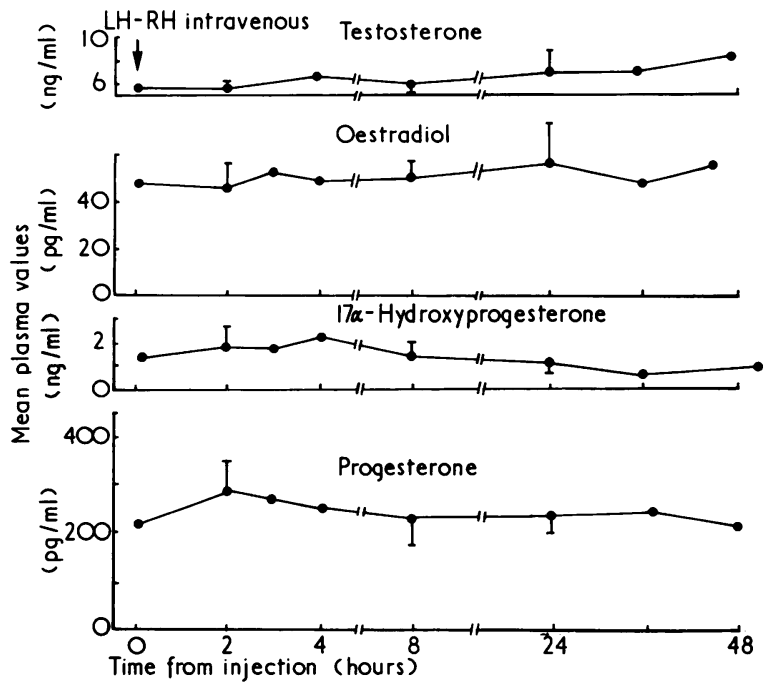

FIG. 5-Effects on gonadal steroid hormones of an intravenous injection of $100 \mathrm{\mu g}$ LH/FSH-RH into four male subjects. Mean and representative S.E.s are shown. 
Gonadal Steroids.-There were no statistically significant changes in any of the four specific gonadal steroid hormones assayed in the male subjects, and this was also true for plasma $17 \beta$-hydroxyandrogens on any dose. The results after $100 \mu \mathrm{g}$ LH/FSH-RH are shown in Fig. 5, and there is a trend suggesting that the plasma testosterone is rising 24 to 48 hours after the dose. In the women plasma oestradiol rose from basal values of 84 and $68 \mathrm{pg} / \mathrm{ml}$ in the two subjects to reach a peak value of 105 and $115 \mathrm{pg} / \mathrm{ml}$ four and eight hours after injection of $100 \mu \mathrm{g} \mathrm{LH} / \mathrm{FSH}-\mathrm{RH}$. This was in response to increases of 4.5 and 6.9 in $\mathrm{LH}, 2.2$ and $3.7 \mathrm{FSH} \mathrm{mU} / \mathrm{ml}$ in the first subject (assays 1 and 2 respectively); and of 7.0 and $2.0 \mathrm{LH}, 0.7$ and $0.7 \mathrm{FSH} \mathrm{mU} / \mathrm{ml}$ in subject 2 ; there were no significant changes in the other gonadal steroids in the women at this dose and none at all after $50 \mu \mathrm{g}$. Serum $G H, T S H$, and plasma cortisol did not change significantly in any subject after any dose.

\section{LIMITED STUDY}

After the initial study a standard LH/FSH-RH test procedure was adopted: $100 \mu \mathrm{g}$ was injected intravenously between 9 and 10 a.m. and blood was sampled before and 20 and 60 minutes afterwards for LH and FSH. Our provisional normal ranges for this test are given in Tables III and IV.

Side Effects. - None were encountered in any subject and the menstrual cycles after administration of $\mathrm{LH} / \mathrm{FSH}-\mathrm{RH}$ were unaltered.

TABLE III-Responses in Serum LH and FSH to $100 \mu \mathrm{g}$ LH/FSH-RH Given Intravenously at 9-10 a.m. in 18 Normal Male Subjects

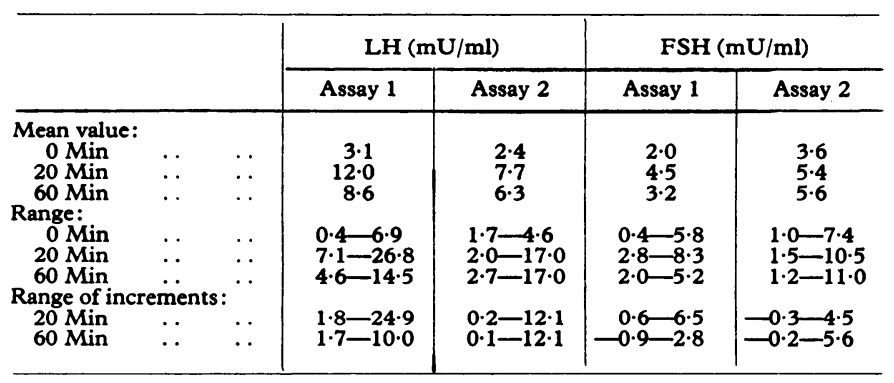

TABLE IV-Responses in Serum LH and FSH to $100 \mu \mathrm{g}$ LH/FSH-RH given TABLE IV-Responses in Serum LH and FSH to $100 \mu \mathrm{g} \mathrm{LH/FSH-RH}$ given
Intravenously at 9-10 a.m. in five Normal Women During Follicular Phases of their Menstrual Cycles

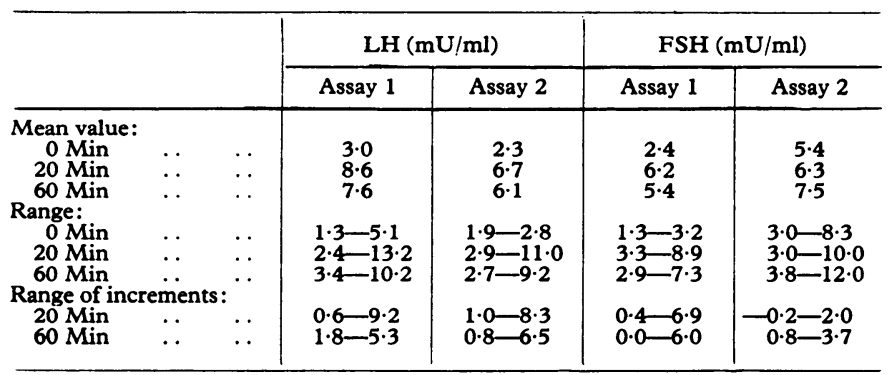

\section{Discussion}

We have shown that in man, as in animals, the synthetic decapeptide $\mathrm{LH} / \mathrm{FSH}-\mathrm{RH}$ is a potent releaser of immunoreactive $\mathrm{LH}$, that the effect is seen within two minutes of an intravenous injection, and that it is dose-dependent over the range of 25 to $100 \mu \mathrm{g}$. In view of the intrinsic lack of specificity and sensitivity of gonadotrophin radioimmunoassays we have validated these conclusions by using two completely different assay systems for each hormone. In all, 25 male and female subjects were given the compound on 32 occasions, and only twice did the serum $\mathrm{LH}$ fail to rise outside the normal range.

There is no doubt that serum immunoreactive FSH also rose in response to $\mathrm{LH} / \mathrm{FSH}-\mathrm{RH}$ since the increments seen could not be accounted for by any cross-reactivity of the antisera used in either assay. We have therefore confirmed that this hormone releases FSH as well as $\mathrm{LH}$ but that it does not affect any of the other non-gonadotrophin pituitary hormones studied, GH, TSH, or ACTH. However, the rise in FSH is much smaller than that of LH, and of the 32 occasions that the substance was administered serum FSH failed to rise outside the normal range 24 times. It remains to be determined whether there is another more specific FSH-releasing hormone or whether the release of $\mathrm{LH}$ or FSH depends on the interaction of circulating gonadal hormone levels and the known $\mathrm{LH} / \mathrm{FSH}-$ RH.

There appear to be no differences between the gonadotrophin responses to LH/FSH-RH in the men or women studied during the follicular phases of their cycles. Preliminary results, however, suggest that much bigger responses in both LH and FSH can be obtained in women during the luteal phases compared with the follicular phases.

In the male subjects there were no statistically significant changes in the circulating gonadal steroid hormones, testosterone and oestradiol, or in their precursors, $17 \alpha$-hydroxyprogesterone or progesterone, in response to the induced $\mathrm{LH}$ and FSH release. The upward trend in plasma testosterone at 48 hours after $100 \mu \mathrm{g} \mathrm{LH} / \mathrm{FSH}-\mathrm{RH}$ suggests that more prolonged gonadal stimulation is required to get a definite response, and either larger doses or different methods of administration of LH/FSH-RH will be necessary. In the women, however, after $100 \mu \mathrm{g}$ of the releasing hormone definite increases in oestradiol were seen, indicating significant follicular stimulation. Further study will indicate the doses required to induce ovulation.

The availability of LH/FSH-RH should provide a powerful therapeutic agent for the treatment of infertility in many women and men. In addition it will provide a useful test of pituitary function in a manner analagous to the use of thyrotrophin-releasing hormone (Hall et al., 1972; Ormston, et al., 1972) in the study of diseases of the thyroid-pituitary axis. The use of LH/FSH-RH in hypogonadal subjects should allow precise localization of the defect at either the hypothalamic, pituitary, or gonadal level. A patient who shows no gonadotrophin response to clomiphene but an adequate response to LH/FSH-RH would be expected to have a lesion above the level of the pituitary, but an absent response to the releasing hormone would indicate pituitary disease. If the clomiphene and $\mathrm{LH} / \mathrm{FSH}-\mathrm{RH}$ responses are present the defect would be in the gonads. Furthermore, elucidation of whether so-called "isolated gonadotrophin deficiencies" are indeed deficiencies of hypothalamic-releasing hormones rather than of pituitary gonadotrophin production will be possible. Such studies are currently in progress. We have defined a simple clinical test procedure involving administration of $100 \mu \mathrm{g} \mathrm{LH} / \mathrm{FSH}-\mathrm{RH}$ intravenously with sampling for LH and FSH before and 20 and 60 minutes afterwards for use when investigating these problems, and we have defined our provisional normal range of responses. However, in view of the inherent problems of gonadotrophin radioimmunoassay it will be necessary for each laboratory to establish its own control data.

We are grateful to Dr. R. Roussel and Dr. W. Bogie, of Hoechst U.K. Ltd., for help and provision of the LH/FSH-RH, to Dr. A. Stockell-Hartree and Dr. W. Butt for the iodination materials, to D. Borthwick, S. Williams, M. McKendrick, A. Hewison, J. Young, P. Hamer, Y. Emment, M. D. Mansfield, E. Youssefnajadian, and J. Woodham for help, and to Professor Russell Fraser and Professor E. F. Scowen for advice.

Requests for reprints should be sent to Dr. G. M. Besser, Medical Professorial Unit, St. Bartholomew's Hospital, London EC1A 7BE. 


\section{References}

Anderson, D. C. (1970). Clinica Chimica Acta, 29, 513.

Collins, W. P. (1972). Scandinavian fournal of Clinical and Laboratory

Investigation. In press.
Hall, R., Ormston, B. J., Besser, G. M., Cryer, R. J., and McKendrick, M. (1972). Lancet, 1,759 .

McCann, S. M., and Dhariwal, A. P. S. (1964). Transactions of the New York Academy of Sciences, 27, 39

McCann, S. M., and Dhariwal, A. P. S. (1966). In Neuroendocrinology, ed. L. Martini, and W. F. Ganong, p. 276. London, Academic Press.
Matsuo, H., Baba, Y., Nair, R. M. G., Arimura, A., and Schally, A. V. (1971). Biochemical and Biophysical Research Communications, 43, 1334. Ormston, B. J., Garry, R., Cryer, R. J., Besser, G. M., and Hall, R. (1972). Lancet, $2,10$.

Schally, A. V., Baba, Y., Arimura, A., Redding, T. W., and White, W. F. (1971a). Biochemical and Biophysical Research Communications, 42, 50 Schally, A. V., et al. (1971b). Biochemical and Biophysical Research Communications, 43, 393.

Schally, A. V., et al. (1971c). Science, 173, 1036.

\title{
Effect of Synthetic Luteinizing Hormone Releasing Hormone (LH/FSH-RH) in Women with Menstrual Disorders
}

\author{
JOHN NEWTON, WILLIAM P. COLLINS
}

British Medical fournal, 1972, 3, 271-273

\section{Summary}

Synthetic luteinizing hormone/follicle stimulating hormone-releasing hormone (LH/FSH-RH) (50 $\mu \mathrm{g})$ was given intravenously to six women with oligomenorrhoea and to four women with secondary amenorrhoea. Peripheral venous blood was withdrawn at regular intervals over a 24-hour period. The concentrations of $\mathrm{LH}$, FSH, and oestradiol-17 $\beta$ were determined by radioimmunoassay. In all subjects there was a variable rise in $\mathbf{L H}$ (3-16 times the mean basal level): in six a small rise in FSH (two to three times the mean basal level) and in seven a twofold to threefold rise in oestradiol three to eight hours after the rise in gonadotrophins.

\section{Introduction}

There is good evidence to believe that the release of luteinizing hormone $(\mathrm{LH})$ and follicle stimulating hormone (FSH) is under a neuroendocrine control emanating from the hypothalamus (Guillemin and Schally, 1963). Evidence for a specific LHreleasing hormone (LH-RH) in rat hypothalamic extracts was first presented by McCann et al. (1960) and in sheep by Courrier et al. (1961).

Recently Schally et al. (1971) showed that a purified extract of pig hypothalami (LH-RH) has both $\mathrm{LH}$ and FSH releasing properties in rats. Human subjects given this purified porcine LH-RH also release LH and FSH (Kastin et al., 1971), as do monkeys, sheep, and rabbits (Reeves et al., 1970; Schally et al., 1970). Kastin et al. (1970) also isolated two fractions from human hypothalami with LH-RH and FSH-RH activity, and when given separately both produced a significant increase in FSH and LH after administration to volunteers.

Schally et al. (1971) proposed a provisional structure for porcine LH-RH, which was revised and found to be a decapeptide (Matsuo et al., 1971). A product with this amino-acid sequence has now been manufactured by Hoechst Pharmaceuticals and was used in the present study.

\footnotetext{
Department of Obstetrics and Gynaecology, King's College Hospital, London S.E.5

\section{Patients and Methods}

Patients selected for this study were all volunteers. They were admitted to hospital on the day before the test and were kept in bed for the duration of the study but were not fasting. A No. 16-gauge angiocath was inserted into an antecubital fossa vein and connected to an extension tube and three-way tap. The tube and angiocath were flushed with heparinized sterile distilled water between each sample. Blood was withdrawn to determine basal hormone levels at 8, 8.30, and 8.50 a.m. A 50- $\mu \mathrm{g}$ dose of synthetic LH-RH (HOE 471) was dissolved in $0.9 \%$ sterile saline solution and diluted to $10 \mathrm{ml}$ in the same material. This was injected via the intravenous line at 9 a.m. Blood samples were then withdrawn at the following times after the injection: $5,10,15,20$, and 30 minutes; and $1,1 \frac{1}{2}, 2,3,6,9$, and 24 hours. The blood samples were centrifuged immediately, the plasma being separated and deep frozen at $-25^{\circ} \mathrm{C}$ until assayed. FSH and $\mathrm{LH}$ were determined by radioimmunoassay using a pituitary standard LER 907 (Wide and Porath, 1966) and oestradiol-17 $\beta$ by radioimmunoassay using an anti-serum to oestradiol-6carboxymethyl oxime-bovine serum albumin (Emment et al., 1972).

The first six patients had oligomenorrhoea with cycles of six to eight weeks. These patients do not have the premenstrual rise in LH and FSH (Newton, 1972c; Ross et al., 1970) which occurs in the normal menstrual cycle (Newton et al., 1971a); the injection of LH-RH was given on the first day of bleeding. The last four patients had secondary amenorrhoea for not less than six months and had previously been investigated to assess their basal endocrine state (Newton 1972a, 1972b).

\section{Results}

The data in Tables I and II show the first significant rise of LH and FSH after the injection of synthetic LH-RH, the time at which the peak level was reached, the duration of raised gonadotrophin levels, and the factorial increase of LH and FSH over the mean basal sample (mean of three). As can be seen from Table $I$ there was a rise in $\mathrm{LH}$ in all 10 patients. Three showed the first significant rise 5 minutes after the injection, five after 10 minutes, and two after 15 minutes. The peak value for $\mathrm{LH}$ was reached after 30 minutes in four patients, 45 in two patients, and 90 minutes in two patients. The duration of response varied from 45 minutes to 8 hours 50 minutes, with five patients between 2 hours 50 minutes and 2 hours 55 minutes. The 